\title{
Determinants of the Arab Spring Protests in Tunisia, Egypt, and Libya: What Have We Learned?
}

\author{
Zahraa Barakat and Ali Fakih *(D) \\ Department of Economics, Lebanese American University, Beirut P.O. Box. 13-5053, Lebanon; \\ zahraa.barakat@lau.edu \\ * Correspondence: afakih@lau.edu.lb
}

Citation: Barakat, Zahraa, and Ali Fakih. 2021. Determinants of the Arab Spring Protests in Tunisia, Egypt, and Libya: What Have We Learned? Social Sciences 10: 282. https://doi.org/10.3390/ socsci10080282

Academic Editors: Timo Kivimaki and Rana Jawad

Received: 2 June 2021

Accepted: 15 July 2021

Published: 23 July 2021

Publisher's Note: MDPI stays neutral with regard to jurisdictional claims in published maps and institutional affiliations.

\begin{abstract}
This paper provides empirical evidence on the determinants of protest participation in Arab Spring countries that witnessed major uprisings and in which social unrest was most pronounced. Namely, this paper investigates the latter in Tunisia, Egypt, and Libya using a micro-level data survey, the Arab Transformation Survey (2015). The findings of our probit regression analysis reveal that gender, trust in government, corruption concern, and social media usage have influenced the individual's perception of protest activism. We find evidence that the role of economic factors was inconsistent, whereas political grievances were more clearly related to the motive to participate in the uprisings. We then control for country-specific effects whereby results show that citizens in each country showed different characteristics of participation. The findings of this research would set the ground for governments to better assess the health of their societies and be a model of governance in the Middle East.
\end{abstract}

Keywords: Arab Spring; participation; protesting; probit model

\section{Introduction}

The political landscape of the Arab states has been significantly shaped by the events of the so-called "Arab Spring". After decades of authoritarianism along with political and civil repression, a sentiment of discontent and disappointment developed throughout the years among Arab residents. The movements began in Tunisia when mass and vicious demonstrations took place against the long dictatorial standards of the tyrant rulers. This inspired other countries in the Middle East and North Africa (MENA) region to undergo similar movements, adopting this activism and making it a powerful tool that matured later in the form local uprisings. Consequently, these riots have reshaped the political in the region (McKay 2011).

Social mobilization is regarded as "conflictual", mainly due to its forms. The protest has been identified as the main foundation of social movements rising the threat of civil wars or conflicts (Porta 2008). The causes of these conflicts are viewed as double-edged. On the one hand, the authorities' inability to meet the continuous demands of citizens has contributed to their grievances (Gurr 1970; Hoadley 1981; Fisher 1990; Collier and Hoeffler 2004). On the other hand, it stems from the state's inability to curb uprisings in a peaceful approach. This results in the state responding with violence, which further entices conflict (Tilly 1978; Mello 2010). Most of the protests in the MENA region were oppressed by brutal measures taken by the state as in Libya and Egypt, while in other cases, appeasement and nonviolent measures were taken, such as in Tunisia.

This paper aims at providing empirical understanding of the determinants contributing to "Arab Spring" uprisings. The paper focuses particularly on the North African countries of Egypt, Libya, and Tunisia where revolutions were more prevalent and the timing of such rebellions were almost simultaneous suggesting that these nations share common features in respect to their long-standing leaders, corrupt government and their educated citizen mainly youth who suffered from unemployment (Anderson 2011, p. 3). 
Revolutions taken place in Tunisia and Egypt were special in respect to their ability to exploit their leaders, while the case of Libya witnessed much more violence adopted by the government to crackdown on protesters.

The findings of this research would set the ground for governments to better assess the health of their societies and set a model of governance in the Middle East. We use a unique dataset extracted from The Arab Transformation Project, which was carried out in 2015. The study employs participation in any "Arab Spring" protests as the dependent variable. The explanatory variables are classified into eight different sets, and empirical analysis is carried out using a probit regression model, which investigates the determinants of taking part in "Arab Spring" protests.

The remainder of this paper is as follows. Section 2 introduces a summary of related literature in the Arab World. Section 3 defines the data and variables included in our model. Section 4 introduces the empirical model and the methodology used. Section 5 elaborates on our findings. Section 6 provides a summary for our research along with recommendations for further studies, and Section 7 provides policy implications according to our findings.

\section{Literature Review}

Examining the literature on democratization and political movements provides a basic guide for understanding the reasons behind the power of the street. Various studies highlight the role of socioeconomic and ideological factors in shaping individuals' beliefs and social and political opinions. Moreover, gender is a vital determinant of political participation as previous research has shown that gender is a determining factor in political pariticpation, perception and engagement (Inglehart et al. 2003; Atkeson 2003; Andersen and Jennings 2010). The Arab Spring participants and particularly youth strongly demanded reforms with respect to economic, educational, and employment reforms and faced with little or no response from their respective governments.

The literature also confirms that unemployment is a determining factor in driving individuals to protest, as a natural outcome of economic frustration over dire economic needs and underutilized potential of human capital (Ottaway and Hamzawy 2011, pp. 4-6; Sadiki 2000). Campante and Chor (2012) indicate that citizens in countries that exhibit high levels of unemployment and rapid educational development show higher tendencies to witness protest movements, including the Arab Spring. Such an approach has been confirmed by Paasonen (2020) who explored the role of unemployment in the "Arab Spring" uprisings. His empirical results show that unemployed individuals are more likely to take part in "Arab Spring" uprisings compared to those who are employed. Likewise, Al-Shammari and Willoughby (2019) suggest that unemployment among youth and regime durability are solid indicators of predicting any revolt or uprising that could result in regime change. In contrast, other arguments refute the hypothesis that illustrates a relationship between unemployment and political participation. For instance, Byun and Hollander (2015) show no evidence for the role of unemployment on the level of demonstrations taking place in "Arab Spring" countries. When studying the case of Tunisia, Doherty and Schraeder (2015) find no employment difference in terms of contributing to protests before the downfall of Ben Ali. Similarly, using the principal wave of the "Arab Barometer" survey, unemployment did not explain the participation in "Arab Spring" in either Tunisia or Egypt (Beissinger et al. 2012).

Several studies cite age and education as key drivers of being engaged in demonstrations. For instance, Paasonen (2020) shows that unsurprisingly being younger and more educated increases the probability of taking part in protest movements. History also shows that youth-rich nations are not afraid of revolting, as they have underutilized potential and growing frustration over the status quo. Nations with younger populations experienced three times more civil conflicts than other countries that had an older population in the 1990s (Terrill 2011). Demographically, the MENA region has a population of about $30 \%$ between 15 and 29 years, which is relatively high and could be one of the factors that the 
region has experienced high levels of violence and conflicts (BBC Trust 2012). Nevertheless, many recent studies confirmed the effect of higher education on political engagement (Henderson and Chatfield 2011; Solis 2013). According to Glaeser et al. (2007), when the economy is struggling to provide the basic opportunities for its youth, the opportunity cost of political commitment tends to be lower including the educated labor, driving all youth have a higher tendency in joining political activism.

Moreover, Aissa (2012) presumes that the expansion in schooling gives rise to a democratic movement. Based on the World Value Survey, Campante and Chor (2014) claim that individuals who obtain a salary with a deficit in their education and biographical attributes reveal more inclination to participate in protests, predicting that educated people who express little trust in their institutions increase the likelihood of their participation in political activities. In other words, when expectations and improvement in education are not met, political violence is more likely to occur (Noland and Pack 2007).

Explanations of the government trust approach are worth noting. Many studies found a link between distrust and protest participation (Jackson 1973; Sears and McConahay 1973; Abravanel and Busch 1975; Citrin 1977) giving insights that protest occurs when people lack trust in their institutions (Muller and Jukam 1977; Muller et al. 1982; Pierce and Converse 1989). Likewise, a low level of trust sets the phase for a violent political protest which can be widely spread to show political instability (Parsons 1963; Coleman 1963, 1970).

Many articles have looked at the role of social media as a catalyst to accelerating social change. Literature on social media draws attention to its vital role in recruiting individuals and mobilizing them through the efficient online coordination of political movements beyond state control (Hussain and Howard 2012; Juris 2012; Diani 2000). Social media is often regarded as a modern resource that enhances communication channels among citizens to call for political demands and express grievances (Pérez 2013), thus resulting in a sense of empowerment, especially to those who are marginalized, to disrupt the monopoly of the authoritarian setting (Radsch and Khamis 2013). It was found that 93 million tweets made by Egyptian women focused on complaints about their states and contributed to the rebellion against the oppression of Mubarak's regime (Ali and Macharia 2013). In this sense, social media became their safe place to discuss their beliefs and speak publicly in times where their culture limited their political engagement (Cattle 2015). Another euphoric aspect of social media is being a useful instrument to spread knowledge, transparency, and raise awareness (Tatarchevskiy 2011; Müller and Hübner 2014), thus facilitating the flow of messages abruptly and impulsively to reach global exposure and support (AlqudsiGhabra 2012). Accordingly, the role of social media in politics was viewed as a threat to governments (Lynch 2011). Focusing on specific social media platforms, Lotan et al. (2011) shed light on the role of Facebook and Twitter in the Egyptian context to connect individuals with local and external communities. Interactive practices have been widely linked to the success of the Arab spring revolution, which was also labeled the "Facebook movement" (Tufekci and Wilson 2012; Lim 2012; Juris 2012). Müller and Hübner (2014) confirmed the latter in the Tunisian context.

However, most social scientists were circumspect if not disruptive. Comunello and Anzera (2012) criticize the Internet's role in the democratization process, arguing that individuals cannot solely depend on the Internet without prior knowledge of international relations theory. Other studies concluded that technology was not the reason behind protesting, but rather how technology was present in distinctive circumstances (Anderson 2011; Samin 2012). Byun and Hollander (2015) conducted an experimental design showing no correlation between a high level of internet connectivity and the level of unrest. Hussain and Howard (2012) focused on the Gulf countries; his results confirmed that increased frequency of social media coverage tended to be associated with a low level of protests. Along similar lines, findings of quantitative models lack the presence of a relationship between frequent use of social media and successful revolutions, concluding that social media is not an adequate instrument for protests. (Dewey et al. 2012). Burris (2011) shed light on the "trap" of the liberation technology paradigm through neo-orientalist tendencies 
in the context of the Arab Spring uprisings. On another note, The Twitter devolution was claimed by Lynch (2013b) to be harmful to the political landscape in Arab countries.

Additionally, the lack of equality, continuous poverty, and deprivation due to the government's denial led to the eruption of mass protests throughout the Arab world. The relative deprivation theory (Gurr 1970) argues that when individuals feel that their rights are left unrecognized, they may deviate towards social activism to have change. The literature on relative deprivation covered vertical inequalities, however, efforts were made to integrate horizontal inequalities, which bring stronger empirical evidence of validity behind conflicts (Cederman et al. 2011).

This deprivation hypothesis is viably clarified by Tunisian residents when the feeling of disparity and denial drove them to demand a democratic system (Kerson 2011). Basic rights such as freedom of speech, political freedom, and the right to vote have been restricted in Tunisia and other countries, motivating citizens to revolt against the political establishment (Müller and Hübner 2014). Thus, inspired by the nearby demonstrations, Libyan citizens refused to settle down and chose to defend their human rights, especially freedom. Such argument was emphasized by an empirical approach to this issue; results show that inequality is an important factor behind an individual's willingness to protest (Parent and Zouache 2017).

Along with lack of prospects, anger over widespread corruption in the MENA government were driving factors for people to take part in the Arab Spring. Research on firm performance in the MENA region has demonstrated a negative relationship between firms engaging in informal activities and firm performance (Abdo Ahmad and Fakih 2021), which in turn translates into lower unemployment rates, triggering protests (Fakih et al. 2020) and leading to a highly frustrated population. Frustration dominated people when they observed the luxurious lifestyle of the elites while most of the population had to grapple with basic necessities (Salamey 2015). For instance, the elites in Arab countries were spending a fortune of money to indulge in their lavish activities rather than helping their economy from drowning (Ogbonnaya 2013). In the case of Egypt, according to ABC News, President Mubarak and his family were charged with a high, unjustified wealth estimated at USD 70 billion (Kim 2011).

There were many calls for controlling the widespread corruption in the MENA region. Many surveys confirmed the urge for the need to root out corruption in Arab countries. For instance, according to a survey done by YouGovCambridge31 in almost eighteen Arab countries, 260,000 respondents mentioned that the major problem in their country is corruption. The "Arab Spring" was believed to be a natural outcome to people's suffering from poverty and unemployment. However, studies showed that the real reason behind these revolutions was the country being ruled by corrupt and unjust dictators. The intensity of the injustice was unbearable to people which led them to riot into the streets and protest against their suffering (Byun and Hollander 2015).

\section{Data and Variables}

We use a micro-level dataset extracted from the Arab Transformation Project, which is coordinated by the University of Aberdeen (UK) in collaboration with other partners (Abbott and Teti 2015). It was conducted by the European Commission's Seventh Framework Program. The latter covers six countries in the MENA region and consists of 12,145 Arab citizens. It establishes surveys that analyze the individual's perception about politics, education, social life, economic state, and governance. However, our study is restricted to Tunisia, Libya, and Egypt, where we examine the factors that influence the individual's decision to protest.

Our dependent variable is participation in "Arab Spring protests", which is a binary variable that equals one if the respondent participates in any Arab Spring protests and zero otherwise. The explanatory variables are divided into different sets. Basic socioeconomic factors, also known as control factors, are included in the first set. It covers gender, a dummy that equals one if the candidate is male and zero otherwise. It also covers age, 
which is defined in years. Additionally, this set covers education, which is captured through two binary variables: (i) No Education, which behaves as a reference variable in our study, and it is equal to one if an individual has an elementary education or below and zero otherwise; (ii) higher education, which equals one if the respondent has a secondary degree and above and zero otherwise. The Employment Status of the respondent also represents another binary variable where being employed takes the value of one, zero otherwise. Finally, the Health Status of the respondents equals one if a respondent claims good health and zero otherwise.

The second set holds Arab Spring factors ranging from Corruption, Authoritarianism, External Interference, Political Freedom, and Economic Problems. The Arab Transformation Survey (2015) asked respondents to identify the most important challenge facing their country and their perception about the reason behind citizens' participation. The set treats these factors as binary, which equals one if the respondent mentioned the above challenges.

The third set contains the Personal Beliefs factors of respondents. It includes the binary variable Social Security which equals one if the respondent feels satisfied with the system of social security and zero otherwise. Similarly, we measure satisfaction with the progress of the economy using a binary variable named Economic Satisfaction. The variable Equality Proponent reflects the tendency to place equality among all by the government, taking a value of one when the respondent believes that their current political system is practicing equality and zero otherwise.

The fourth set takes into account the Confidence in Institutions factors which consider binary variables of Corruption Concern, a variable asking candidates about their opinion of the government's effort in cracking down on corruption. Furthermore, a good extent in rooting out corruption is represented by the value of one, and zero otherwise. Similarly, for the Job Creation variable that equals one if the respondent believes that the government is doing well in creating job opportunities. Finally, the Trust in Government indicator equals one if individual shows trust for the government and zero otherwise.

The fifth set incorporates Poverty measures by comparing a household's income and expenses. The variable is equal to one if individuals' income was not sufficient to cover their expenses and zero otherwise.

The economic factor is covered in the sixth set where respondents evaluate the status of the economy at the current time. The National Economy variable, if equals to one, indicates good evaluation for the national economy and zero otherwise.

The seventh set employs Internet usage as a proxy variable for all forms of social media taking the value of one of the corresponding respondents uses the internet frequently, and zero otherwise.

The last set adds Country Dummies to control for the variation in countries applying Tunisia as a reference country in the empirical regression.

\section{Methodology}

Given the binary nature of the dependent variable, either the logit or probit method can be utilized. Although they differ in the distribution function, both methods produce similar results. After checking for robustness, the probit model was chosen in this paper using the Arab Transformation (2015) data to investigate the determinants of individual's participation in "Arab Spring" protests.

The explanatory variables mentioned above are expected to exhibit correlation and therefore Variance Inflation Factors (VIFs) are used to detect multicollinearity. Given that the average score is below 10 and VIFs show a value less than 5, we conclude that our model shows no problematic correlation between the explanatory variables as can be shown in Table 1. To this end, the model is said to be reliable. 
Table 1. Collinearity diagnostics among the explanatory variables.

\begin{tabular}{ccccc}
\hline Variable & VIF & SQRT VIF & Tolerance & R-Squared \\
\hline Male & 1.34 & 1.16 & 0.7452 & 0.2548 \\
Age & 1.50 & 1.23 & 0.6649 & 0.3351 \\
Employed & 1.34 & 1.16 & 0.7488 & 0.2512 \\
Higher education & 1.49 & 1.22 & 0.6711 & 0.3289 \\
Health & 3.82 & 1.95 & 0.2617 & 0.7383 \\
Against corruption & 1.20 & 1.10 & 0.8336 & 0.1664 \\
External interference & 1.03 & 1.01 & 0.9731 & 0.0269 \\
Economic problems & 1.40 & 1.18 & 0.7134 & 0.2866 \\
Authoritarian leaders & 1.29 & 1.13 & 0.7771 & 0.2229 \\
Political freedom & 1.27 & 1.13 & 0.7878 & 0.2122 \\
Equality & 4.00 & 2.00 & 0.2498 & 0.7502 \\
Economic satisfaction & 1.66 & 1.29 & 0.6027 & 0.3973 \\
Social security & 1.33 & 1.15 & 0.7538 & 0.2462 \\
Trust government & 1.57 & 1.25 & 0.6385 & 0.3615 \\
Job creation & 1.38 & 1.17 & 0.7252 & 0.2748 \\
Corruption concern & 1.26 & 1.12 & 0.7938 & 0.2062 \\
Poverty & 1.20 & 1.09 & 0.8360 & 0.1640 \\
National economy & 1.04 & 1.02 & 0.9603 & 0.0397 \\
Social media & 1.41 & 1.19 & 0.7069 & 0.2931 \\
\hline
\end{tabular}

The probit equation is estimated as follows:

$$
P A R T_{i}=\alpha_{0}+\alpha_{1} S E_{i}+\alpha_{2} A S_{i}+\alpha_{3} P B_{i}+\alpha_{4} C I_{i}+\alpha_{5} P O V+\alpha_{6} E C_{i}+\alpha_{7} S M_{i}+\alpha_{8} C_{i}+\varepsilon_{i}
$$

where $P A R T_{i}$ is a binary variable that equals one if the respondent (i) participates in any Arab Spring protests. The other variables (explanatory) represent individuals' characteristics present in the survey's dataset. $S E, A S, P B, C I, P O V, E C, S M$, and $C$, stand for Socioeconomic, Arab Spring, Personal Beliefs, Confidence in institution, Poverty, Economic, and Social Media factors, respectively, in addition to the country dummies. The error term which follows a normal distribution is represented by $\varepsilon_{i}$.

Table 2 presents the descriptive statistics for the variables of interest representing some of the characteristics of the respondents. It is shown that $34 \%$ of respondents participated in some sort of protests within the Arab Revolutions, 32\% of respondents are Egyptian, $39 \%$ are Libyan, and $29 \%$ are Tunisian. We find that $50 \%$ of the candidates are males; the average age of those who were engaged in revolts is 39 years old. We also observe that $37 \%$ are employed, $76 \%$ obtained higher education, and $41 \%$ are highly active on social media platforms. The Arab Transformation Survey (2015) asked respondents to identify the challenges and reasons that they believed citizens participated in their societies, $57 \%$ claimed that corruption was the reason, only $6 \%$ identified external interference as a cause for protesting, $41 \%$ contributed demonstration for economic grievances, $23 \%$ believed that people were joining protests to oppose authoritarian leaders, and $22 \%$ mentioned that citizens were brought to streets to demand political freedom. When asking respondents about their current political system, $72 \%$ stated that there is a good extent in spreading equality, 32\% were satisfied with the economic development, and 35\% were satisfied with the social security system. Moreover, opinions at the institutional level show that only $30 \%$ trust their government, $26 \%$ believe that the government is showing a good effort in creating job opportunities, and $44 \%$ admit that the government is working on cracking down on corruption. At a personal belief level, $45 \%$ mentioned that they are poor since their income level is not enough in covering their expenses. Surprisingly, only $4 \%$ believed that the national economy obtains a good status. 
Table 2. Summary statistics of variables.

\begin{tabular}{ccc}
\hline & Mean & Standard Deviation \\
\hline Dependent variable & & \\
Participation & 0.34 & 0.47 \\
Independent variables & & \\
Male & 0.50 & 0.50 \\
Age & 39.35 & 14.20 \\
Employed & 0.37 & 0.48 \\
Higher education & 0.76 & 0.43 \\
Health & 0.60 & 0.49 \\
Against corruption & 0.57 & 0.50 \\
External interference & 0.06 & 0.23 \\
Economic problems & 0.41 & 0.49 \\
Authoritarian leaders & 0.23 & 0.42 \\
Political freedom & 0.22 & 0.41 \\
Equality & 0.72 & 0.45 \\
Economic satisfaction & 0.32 & 0.46 \\
Social security & 0.35 & 0.48 \\
Trust government & 0.30 & 0.46 \\
Job creation & 0.26 & 0.44 \\
Corruption concern & 0.44 & 0.50 \\
Poverty & 0.45 & 0.50 \\
National economy & 0.04 & 0.20 \\
Social media & 0.41 & 0.49 \\
Egypt & 0.32 & 0.47 \\
Libya & 0.39 & 0.49 \\
Tunisia & 0.30 & 0.46 \\
$N N$ & 3994 & \\
\hline
\end{tabular}

\section{Empirical Results}

\subsection{Main Results}

Table 3 interprets the marginal effects resulted from the probit model of the determinants of the protest participation in the Arab Spring. Each column represents one of the specifications described earlier in the data and variables section.

Table 3. Determinants of the decision to participate in Arab spring protests (probit model, marginal effects).

\begin{tabular}{|c|c|c|c|c|c|c|c|c|}
\hline & (1) & (2) & (3) & (4) & (5) & (6) & (7) & (8) \\
\hline \multicolumn{9}{|l|}{ Socio-economic factors } \\
\hline \multirow[t]{2}{*}{ Male } & $0.471^{* * *}$ & $0.468^{* * *}$ & $0.462 * * *$ & $0.503^{* * *}$ & $0.528 * * *$ & $0.540^{* * *}$ & $0.585^{* * *}$ & $0.706^{* * *}$ \\
\hline & $(0.064)$ & $(0.065)$ & $(0.084)$ & $(0.090)$ & $(0.091)$ & $(0.092)$ & $(0.094)$ & $(0.101)$ \\
\hline \multirow[t]{2}{*}{ Age } & $-0.014^{* * *}$ & $-0.014 * * *$ & $-0.013^{* * *}$ & $-0.014^{* * *}$ & $-0.014 * * *$ & $-0.016^{* * *}$ & $-0.008^{* *}$ & -0.006 * \\
\hline & $(0.002)$ & $(0.002)$ & (0.003) & (0.003) & $(0.003)$ & (0.003) & $(0.003)$ & $(0.004)$ \\
\hline \multirow[t]{2}{*}{ Employed } & $0.116^{*}$ & $0.111^{*}$ & $0.146^{*}$ & $0.186^{* *}$ & 0.160 * & 0.164 * & 0.121 & 0.013 \\
\hline & $(0.065)$ & $(0.066)$ & $(0.085)$ & $(0.090)$ & $(0.091)$ & $(0.092)$ & $(0.094)$ & (0.099) \\
\hline \multirow[t]{2}{*}{ Higher education } & $0.518^{* * *}$ & $0.439 * * *$ & $0.523^{* * *}$ & $0.484^{* * *}$ & $0.428^{* * *}$ & $0.405^{* * *}$ & 0.225 * & 0.044 \\
\hline & $(0.074)$ & $(0.076)$ & $(0.103)$ & $(0.112)$ & $(0.117)$ & $(0.118)$ & $(0.124)$ & $(0.132)$ \\
\hline \multirow[t]{2}{*}{ Health } & $-0.120^{* *}$ & $-0.119^{* *}$ & 0.102 & 0.059 & 0.170 & 0.194 & 0.150 & 0.301 \\
\hline & $(0.056)$ & $(0.058)$ & $(0.171)$ & $(0.175)$ & $(0.179)$ & $(0.182)$ & $(0.186)$ & $(0.198)$ \\
\hline \multicolumn{9}{|l|}{ Arab Spring factors } \\
\hline \multirow[t]{2}{*}{ Against corruption } & & $0.342 * * *$ & $0.284^{* *}$ & $0.218 * *$ & $0.214^{* *}$ & $0.229 * *$ & 0.175 * & $0.179 *$ \\
\hline & & $(0.064)$ & $(0.084)$ & $(0.090)$ & $(0.092)$ & $(0.093)$ & $(0.096)$ & $(0.100)$ \\
\hline \multirow[t]{2}{*}{ External interference } & & 0.153 & -0.005 & -0.003 & 0.027 & -0.054 & -0.046 & -0.149 \\
\hline & & $(0.124)$ & $(0.166)$ & $(0.174)$ & $(0.176)$ & $(0.183)$ & $(0.186)$ & $(0.206)$ \\
\hline \multirow[t]{2}{*}{ Economic problems } & & -0.069 & -0.137 & -0.148 & -0.137 & -0.137 & -0.113 & 0.164 \\
\hline & & $(0.068)$ & $(0.090)$ & $(0.096)$ & $(0.098)$ & $(0.099)$ & $(0.102)$ & $(0.111)$ \\
\hline \multirow[t]{2}{*}{ Authoritarian leaders } & & $0.393 * * *$ & $0.243 * *$ & $0.192 *$ & 0.152 & 0.171 & $0.195 *$ & 0.100 \\
\hline & & $(0.074)$ & $(0.098)$ & $(0.103)$ & $(0.106)$ & $(0.107)$ & $(0.110)$ & $(0.115)$ \\
\hline \multirow[t]{2}{*}{ Political freedom } & & $0.432 * * *$ & $0.339^{* * *}$ & $0.295^{* * *}$ & $0.277^{* * *}$ & $0.268^{* *}$ & $0.269 * *$ & 0.177 \\
\hline & & $(0.073)$ & $(0.094)$ & $(0.101)$ & $(0.103)$ & $(0.105)$ & $(0.109)$ & $(0.116)$ \\
\hline Personal Beliefs factors & & & & & & & & \\
\hline
\end{tabular}


Table 3. Cont.

\begin{tabular}{|c|c|c|c|c|c|c|c|c|}
\hline & (1) & (2) & (3) & (4) & (5) & (6) & (7) & (8) \\
\hline Equality & & & $\begin{array}{l}-0.059 \\
(0.159)\end{array}$ & $\begin{array}{c}0.089 \\
(0.163)\end{array}$ & $\begin{array}{l}-0.026 \\
(0.167)\end{array}$ & $\begin{array}{l}-0.052 \\
(0.170)\end{array}$ & $\begin{array}{c}0.031 \\
(0.175)\end{array}$ & $\begin{array}{l}-0.032 \\
(0.186)\end{array}$ \\
\hline Economic satisfaction & & & $\begin{array}{l}-0.377^{* * * *} \\
(0.093)\end{array}$ & -0.111 & -0.085 & -0.069 & -0.043 & 0.124 \\
\hline Social security & & & $\begin{array}{c}(0.093) \\
0.185^{* *} \\
(0.085)\end{array}$ & $\begin{array}{c}0.207^{* * *} \\
(0.093)\end{array}$ & $\begin{array}{l}(0.112) \\
0.156 \\
(0.095)\end{array}$ & $\begin{array}{c}(0.113) \\
0.145 \\
(0.097)\end{array}$ & $\begin{array}{l}(0.116) \\
0.173 * \\
(0.099)\end{array}$ & $\begin{array}{l}(0.128) \\
0.188^{*} \\
(0.105)\end{array}$ \\
\hline \multicolumn{9}{|c|}{ Confidence in institutions factors } \\
\hline Trust government & & & & $\begin{array}{c}-0.726^{* * *} \\
(0.112)\end{array}$ & $\begin{array}{c}-0.691^{* * *} \\
(0.113)\end{array}$ & $\begin{array}{c}-0.690 * * * \\
(0.115)\end{array}$ & $\begin{array}{c}-0.707^{* * *} \\
(0.118)\end{array}$ & $\begin{array}{c}-0.505^{* * *} \\
(0.128)\end{array}$ \\
\hline Job creation & & & & $\begin{array}{c}0.245^{* *} \\
(0.108)\end{array}$ & $\begin{array}{c}0.221 * * \\
(0.110)\end{array}$ & $\begin{array}{c}0.239 * * \\
(0.111)\end{array}$ & $\begin{array}{l}0.212 * \\
(0.114)\end{array}$ & $\begin{array}{c}0.143 \\
(0.123)\end{array}$ \\
\hline Corruption concern & & & & $\begin{array}{c}-0.1084^{* * *} \\
(0.086)\end{array}$ & $\begin{array}{c}-0.269^{* * *} \\
(0.088)\end{array}$ & $\begin{array}{c}-0.265^{* * *} \\
(0.089)\end{array}$ & $\begin{array}{c}-0.208^{* *} \\
(0.091)\end{array}$ & $\begin{array}{c}-0.272^{* * *} \\
(0.097)\end{array}$ \\
\hline \multicolumn{9}{|l|}{ Poverty factors } \\
\hline Poverty & & & & & $\begin{array}{c}-0.263^{* * *} \\
(0.087)\end{array}$ & $\begin{array}{c}-0.288^{* * *} \\
(0.089)\end{array}$ & $\begin{array}{l}-0.151 \\
(0.093)\end{array}$ & $\begin{array}{c}0.030 \\
(0.099)\end{array}$ \\
\hline \multicolumn{9}{|l|}{ Economic factors } \\
\hline National economy & & & & & & $\begin{array}{l}0.570 * \\
(0.328)\end{array}$ & $\begin{array}{l}0.620 * \\
(0.334)\end{array}$ & $\begin{array}{c}0.334 \\
(0.363)\end{array}$ \\
\hline \multicolumn{9}{|l|}{ Social media factors } \\
\hline Social media & & & & & & & $\begin{array}{c}0.763 * * * \\
(0.096)\end{array}$ & $\begin{array}{c}0.662 * * * \\
(0.103)\end{array}$ \\
\hline \multicolumn{9}{|l|}{ Country Dummy } \\
\hline Egypt & & & & & & & & $\begin{array}{l}-0.301 * * \\
(0.141)\end{array}$ \\
\hline Libya & & & & & & & & $\begin{array}{c}1.043 \\
* *(0.111)\end{array}$ \\
\hline Constant & $\begin{array}{c}-0.555 \text { ** } \\
(0.125)\end{array}$ & $\begin{array}{c}-0.872 * * * \\
(0.147)\end{array}$ & $\begin{array}{c}-0.910 * * * \\
(0.209)\end{array}$ & $\begin{array}{c}-0.731^{* * *} \\
(0.226)\end{array}$ & $\begin{array}{c}-0.574^{* *} \\
(0.241)\end{array}$ & $\begin{array}{c}-0.519 * * \\
(0.244)\end{array}$ & $\begin{array}{c}-1.112^{* * *} \\
(0.265)\end{array}$ & $\begin{array}{c}-1.577^{* * * *} \\
(0.288)\end{array}$ \\
\hline$N$ & 2439 & 2439 & 1426 & 1299 & 1268 & 1246 & 1240 & 1240 \\
\hline
\end{tabular}

Note: No education category is the reference group for higher education variable. Statistical significance: ${ }^{*} 10 \%,{ }^{* *} 5 \%,{ }^{* * *} 1 \%$; Robust standard errors are reported in parentheses.

Column 1 presents the Socioeconomic variables, which behave as a control group to our study. Results indicate that gender, age, educational attainments, and health status are related to protest involvement, while employment does not matter. This result seems to be surprising taking into consideration earlier research that acknowledged the role of unemployment behind the so-called "Arab Spring" protest, except in light of the findings of Paasonen, 2020, who addressed the gaps of previous studies mainly in raising the problem of measuring unemployment. In her paper, unemployment was not regarded as a major force instigating individuals towards rebellion. Whilst various sources of conflict exist simultaneously, there is no denying that the dominant source of political problems in the MENA region stems from factionalism in politics. Such subnational challenges to the state have inevitably caused a growing doubt around the state's political legitimacy and could perhaps be the determining factor behind state fragility in the MENA region (Kivimäki 2021).

The findings indicate that males are engaged in demonstration $16 \%$ more than females. In addition, age and health status are negatively correlated to protesting, implying that political uprisings are associated with a higher likelihood of protest participation among youth and those who have poor health. Result for education, however, contributed with a higher propensity of protest participation among educated people. These findings are consistent with (Paasonen 2020; Noland and Pack 2007).

Column 2 incorporates Arab Spring factors. Corruption, authoritarianism, and political freedom show statistical evidence in support of the reason behind protest participation. These findings coincide with the narrative that protestors have been triggered by democratic and anticorruption reform ((Müller and Hübner 2014; Byun and Hollander 2015; Aissa 2012). 
Column 3 adds personal beliefs variables. Health did not seem to impact an individual's participation anymore. We find significant evidence that individuals who are dissatisfied with the economic development show a greater tendency to engage in protest activism. The continuous poor efforts by the government to boost the economy push individuals to express discontent (Arampatzi et al. 2018). Surprisingly, our finding reveals that people who feel satisfied with the social security system are more likely to participate in protests compared to those who are dissatisfied. This unfamiliar result is consistent with other studies that speak for higher levels of participation among individuals who benefit from social welfare (McCarthy and Zald 1977; Klandermans 1997; Theiss and Kurowska 2019). Ideally, receiving satisfying social welfare empowers them to take part in political activities in the form of political transition; on the contrary, dissatisfied people are helpless in bringing about political change.

Column 4 presents Confidence in Institution factors. Authoritarianism and Satisfaction with the economic development lost their significance behind prioritizing protests whereas employment status showed positive and significant results implying that employed are more likely to have been engaged in rebellions. This suggests that the unemployed might have less interest in politics, which decreases the likelihood of revolt (Paasonen 2020).

We also find that individuals who show no trust in the government are more likely to participate, as concluded by Campante and Chor (2014). Additionally, there is evidence that cracking down on corruption by the government decreases the likelihood to bring people into the streets. This compulsion may be a reasonable result of massive calls to offset the level of corruption. Curiously, respondents who believe that the government is doing good efforts in creating jobs are $8.5 \%$ more likely to be involved in protests than those who gave bad evaluations for job opportunities. There is a gap in providing any empirical evidence to approve the link between job creation and increased stability. Developing a typical comprehension of the stability term enables more understanding of the linkage between job creation and stability (Bergh and Zanker 2013).

Column 5 , which incorporates poverty measures, shows that $8.7 \%$ of those whose income does not cover their expenses are less likely to be inclined in protest than those whose income is sufficient for their needs. We would have expected the relationship to be positive instead of negative, as proved by other studies according to the deprivation theory (Kerson 2011; Parent and Zouache 2017). Our results imply that the political conditions of the MENA region explain the desire to rebel rather than economic distresses. This in turn distinguishes MENA countries from the rest of the world, especially South Asia. Moreover, Social Security and the employment variable became statistically insignificant.

Column 6 introduces the Economic factor: National Economy. We found no statistical relationship between national economy status and protesting. Unlike other studies which claim that the economy is declining due high level of inflation, individuals show more propensity towards protesting (Byun and Hollander 2015).

Column 7 accounts for adding the Social Media factor, obviously some variables such as higher education, corruption, job creation, and poverty flipped their significance. However, we obtain significant results indicating that frequency in using social media increases the probability of joining protests. This emphasizes the role of social media in antigovernment movements (McKay 2011; Chokoshvili 2011).

Lastly, column 8 introduces Country dummies. The results show that gender, trust in government, corruption concern, and social media usage influence protesting decisions for revolts, while other factors display no significance. Results are consistent with the other studies (Andersen and Jennings 2010; Muller et al. 1982; Chokoshvili 2011; McKay 2011).

Compared to Tunisia, Egyptian citizens are $9.4 \%$ less likely to participate in protests, whereas Libyan residents are $36 \%$ more likely to be engaged in revolutions. A likely explanation for dispersion in participation rate can be due to differences in population size, cultural and societal factors. Of note, our explanatory power increased when moving from column 1 to column 8 as the pseudo R2 increased from $8 \%$ to around 30\% when proceeding with the model, indicating that our model is an excellent fit when adding all variables. 


\subsection{Heterogeneous Effects across Countries}

Table 4 reports the marginal effects from the probit model of determinants of protest participation across the studied countries. Each column corresponds to specifications discussed earlier across each country separately.

Table 4. Determinants of the decision to participate in Arab Spring by country (marginal effects).

\begin{tabular}{|c|c|c|c|}
\hline & Egypt & Libya & Tunisia \\
\hline \multicolumn{4}{|l|}{ Socio-economic factors } \\
\hline \multirow[t]{3}{*}{ Male } & $0.406^{*}$ & $0.587^{* * *}$ & $0.917^{* * *}$ \\
\hline & $(0.239)$ & $(0.176)$ & $(0.165)$ \\
\hline & 0.005 & 0.002 & $-0.021^{* * *}$ \\
\hline Age & $(0.007)$ & $(0.007)$ & $(0.007)$ \\
\hline \multirow[t]{2}{*}{ Employed } & 0.146 & 0.175 & -0.146 \\
\hline & $(0.233)$ & $(0.182)$ & $(0.160)$ \\
\hline \multirow[t]{2}{*}{ Higher education } & 0.063 & 0.098 & -0.173 \\
\hline & $(0.230)$ & $(0.344)$ & $(0.208)$ \\
\hline \multirow[t]{2}{*}{ Health } & $0.817^{* *}$ & 0.467 & -0.456 \\
\hline & $(0.395)$ & $(0.367)$ & $(0.348)$ \\
\hline \multicolumn{4}{|l|}{ Arab Spring factors } \\
\hline \multirow{2}{*}{ Against corruption } & $0.453^{* *}$ & $0.401 * *$ & -0.285 \\
\hline & $(0.207)$ & $(0.175)$ & $(0.182)$ \\
\hline \multirow{2}{*}{ External interference } & -0.474 & 0.216 & -0.840 \\
\hline & $(0.448)$ & $(0.308)$ & $(0.648)$ \\
\hline \multirow[t]{2}{*}{ Economic problems } & 0.344 & 0.381 & -0.174 \\
\hline & $(0.248)$ & $(0.216)$ & $(0.180)$ \\
\hline \multirow[t]{2}{*}{ Authoritarian leaders } & 0.574 & 0.075 & 0.015 \\
\hline & $(0.328)$ & $(0.184)$ & $(0.189)$ \\
\hline \multirow[t]{2}{*}{ Political freedom } & 0.440 & $0.414^{* *}$ & -0.266 \\
\hline & $(0.269)$ & $(0.189)$ & $(0.212)$ \\
\hline \multicolumn{4}{|l|}{ Personal-Belief factors } \\
\hline \multirow[t]{2}{*}{ Equality } & $-0.999 * * *$ & 0.097 & $0.595^{*}$ \\
\hline & $(0.365)$ & $(0.354)$ & $(0.330)$ \\
\hline \multirow[t]{2}{*}{ Economic Satisfaction } & $0.595 * *$ & -0.198 & 0.191 \\
\hline & $(0.261)$ & $(0.228)$ & $(0.236)$ \\
\hline \multirow[t]{2}{*}{ Social security } & 0.038 & $0.514^{* * *}$ & 0.033 \\
\hline & $(0.219)$ & $(0.191)$ & $(0.187)$ \\
\hline \multicolumn{4}{|c|}{ Confidence in institution factors } \\
\hline \multirow[t]{2}{*}{ Trust government } & -0.359 & $-0.814^{* * *}$ & -0.153 \\
\hline & $(0.244)$ & $(0.225)$ & $(0.244)$ \\
\hline \multirow[t]{2}{*}{ Job creation } & 0.096 & 0.203 & 0.093 \\
\hline & $(0.205)$ & $(0.213)$ & $(0.283)$ \\
\hline \multirow[t]{2}{*}{ Corruption concern } & -0.329 & -0.166 & -0.226 \\
\hline & $(0.234)$ & $(0.155)$ & $(0.171)$ \\
\hline \multicolumn{4}{|l|}{ Poverty factors } \\
\hline \multirow[t]{2}{*}{ Poverty } & -0.223 & 0.010 & $0.285 *$ \\
\hline & $(0.206)$ & $(0.184)$ & $(0.168)$ \\
\hline \multicolumn{4}{|l|}{ Economic factors } \\
\hline & $0.541(0.565)$ & $-0.165(0.511)$ & \\
\hline Social media factors & & & \\
\hline Social media & $0.475 *$ & $0.573 * * *$ & $0.954 * * *$ \\
\hline & $(0.261)$ & $(0.156)$ & $(0.192)$ \\
\hline Constant & $-2.407^{* * *}$ & $-1.341^{* *}$ & -0.483 \\
\hline & $(0.620)$ & $(0.564)$ & $(0.478)$ \\
\hline$N$ & 422 & 382 & 435 \\
\hline
\end{tabular}

Note: No education category is the reference group for higher education variable. Statistical significance: ${ }^{*} 10 \%$ $* * 5 \% * * * 1 \%$; Robust standard errors are reported in parentheses.

The unconditional marginal effects in Egypt show that those who claim good health are $6.4 \%$ more likely to participate in protests than those with poor health. Corruption was shown to be a significant reason for bringing people to the streets. The result is in line with a recent study arguing that corruption brought a wave of dissatisfaction among Egyptians, leading them to protest (Saidin 2018). 
Egyptians who mentioned that their current political system is much better at providing equality among individuals are $18.8 \%$ less likely to be engaged in protests. Such a conclusion was argued by Acemoglu et al. (2005) through the social equality approach. Thus, suggesting that Egyptians who support and call for the principle of equality tend to fear less political engagement compared to those that are less adherent to this principle (Fakih and Ghazalian 2019). Still, those who are satisfied with how the economy is developing are $6.3 \%$ more probable to demonstrate. Though improved economic conditions would lower unemployment, it is more likely to cause a higher degree of insurgencies (Berman et al. 2011).

Hence, the results give us an insight that those who are satisfied with the economic condition would be engaged in revolutions due to their belief that they are the advocates for the country, not the oppressive leaders.

Similar to Egypt, corruption also tends to matter for Libyan protestors in addition to the urge for political freedom; yet Libya shows a gender gap where male shows more tendency towards protesting. In February 2011, protestors raised their call for democratic changes, the rejection of corruption, and against the violation of human rights (Lynch 2013a). The lack of trust in government accounts for higher engagement in protests. It is worth mentioning that those who are better off in social security are more likely to join revolts than those who are dissatisfied. Those who are better off are more likely to protest, not necessarily those who are poor and helpless (Klandermans 2011). Notably, social media had a significant impact on Libyan people towards democracy as $21 \%$ of those who use social media show a higher likelihood to protest. Though the Libyan governments tried to limit internet access, which seemed to be a threat to the authoritarian regimes, protestors used Twitter to post and share information (Gire 2017).

For one thing, none of the reasons behind the protest were significant for Tunisia. In addition, revolutionary participants in other countries showed no significant difference in age except in Tunisia, which shows a negative and significant relationship between age and participation, but the magnitude remains very low $(0.5 \%)$. Being a male and an active user on social media increases the likelihood of participation in demonstrations. Social media was an effective tool impacting the path of Arab spring in Tunisia, which displayed a peak after the self-immolating incident of "Mohammad Bouazizi" whose act had considerable impacts on the Arab world (Hussain and Howard 2012).

\section{Conclusions}

This paper examines the factors behind participation in the Arab Spring demonstrations in Tunisia, Egypt, and Libya. Findings for all three countries reveal that set of socioeconomic and sociopolitical factors have established a motivation behind an individual's decision to protest. The willingness to participate in uprisings was shown to be driven by political grievances rather than economic factors. The intention of such a result may reinforce the main determinant for conflict in weak MENA communities, suggesting that aspects of state fragility in MENA seem to be different than other societies in the world (Kivimäki 2021).

We find that the gender gap is significant in the examined sample, lack of trust in government showed to be a significant trigger towards protesting, social media played an essential role in influencing people to take part in protests, and governments' attempts to combat corruption tend to decrease the probability of bringing people into streets. Indeed, each country had its roots for the uprisings; hence, our results show a substantial difference among the studied countries in citizens' pattern toward rebellion. For instance, corruption and inequality seemed to increase the likelihood of protest participation in Egypt. We also find evidence that Egyptians with good health and who are satisfied with the economic development in their countries were engaged in political activism more often than those who are dissatisfied. As for Libyan citizens, males were more probable to join revolts. It was found that corruption, political freedom, lack of trust in government, and social media usage are the main drivers to prompt the protesting mechanism in Libya; however, 
satisfaction with the social security played a positive role in influencing people to join revolts. Lastly, Tunisia showed a gender gap difference in protest involvement. Regardless of the low magnitude, youth engagements tend to be significant, and usage of social media was correlated with a higher likelihood for political participation.

To further validate our findings, we can include other countries, increasing our sample size to helps us draw more accurate generalizations. Adding more economic indicators that were unfeasible to us and essential in having a better understanding whether participants were motivated by political change or economic grievances.

To reach a more diversified understanding of the "Arab Spring" and its broader implications requires looking at their margins; hence, the narration of the "Arab Spring" employing a more in-depth approach. Although revolts used the same slogans calling for freedom and the fall of the "regime", considering them as a single revolution indicates a misguided viewpoint given the differences between distinct Arab countries (Ventura 2016, p. 285). Many groups anticipated their movements such as the "Arab Spring" for recognition purposes. On the other hand, terms such as Arab awakening is linked to a "Neo-Orientalist" world-view calling for people's awareness in the Arab world about the West's approach to portraying them as oppressed, under-civilized, and lacking agency, to the idea of "Arab despotism" and the belief that Western philosophical theology is the only path towards modernity, or the "Islamist Winter", which was employed to swing the focus of the social movement to political and security threats (Huber and Kamel 2015, p. 129; Al-Kassimi 2021). In this context, the representation of the events taking place in MENA seems to be generalized and associated with the myth of "Oriental despotism" (Ventura 2016, p. 286). The neo-orientalist approach can be recognized based on how rebellions were gendered by considering how Arab women were seen as victims of oppression and required saving (Al-Kassimi 2021). For instance, Western media deployed a gendered issue out of the uprisings and the continuous calls for women's rights confirm their "Orientalism" (Mahmood 2006; Abu-Lughod 2013; Abbas 2014; Ventura 2016, p. 291). Moreover, to state that all Arab are Muslims represents a neo-Orientalist myth (Mahmood 2006; Abu-Lughod 2013; Abbas 2014). The participation of women in the protest challenges the neo-orientalist approach whereby a broad range of females were involved in the protests. Whether on the ground or their heavily online presence on social media platforms, such as Leila-Zahra, Esraa Abdel-Fattah, and Lina Ben Mhenne, they played a major role as activists in women empowerment agenda. Such a deterministic frame necessitates a deeper recognition and deconstruction (Khalid 2015, p. 163). Of note, Western modernity has refuted the ideology of Arab women as being rational and competent authors of their political lives by limiting the intricacy of Arab cultural heterogeneity across the Mashreq and Maghreb (Al-Kassimi 2021, p. 26).

\section{Policy Implications}

Understanding the factors that gave rise to the uprising helps to better assess the health of our society and to provide guidance for strategies ensuring political stability. Governments shall rely on two main pillars to build citizenship and minimize the risk of political instability. The first pillar is forming an anticorruption ecosystem by taking solid and firm actions to fight the existing corruption. Some measures include restructuring the judicial system to avoid bribes and irregular payments, investigating and penalizing those involved in corrupt acts within the public administration, and seizing assets where wealth cannot be explained, subject to judicial oversight (Morgan 1998). The second pillar is building transparency and trust between citizens and the government. Though efforts to earn public trust are limited, transparency is assumed to be crucial (Kettl 2017). A vital prerequisite for that is creating portals where government spending is published regularly allowing citizens to track all the ongoing projects and initiatives. It is worth noting that governments can adopt social media to provide complementary information broadcasting, communication, and participation channels whereby citizens can access government services and also government officials be able to make more informed decisions. Countries 
can also put citizens at the heart of policy making by offering them the opportunity to shape legislation in areas that they care most about by voting on policy proposals. Transparent, unbiased, and inclusive policy making helps in improving democratic performance (Shah 2007).

Author Contributions: Z.B. and A.F. contributed equally to this work. Both authors have read and agreed to the published version of the manuscript.

Funding: This research received no external funding.

Informed Consent Statement: Not applicable.

Data Availability Statement: Data used in this paper are publically available from https://www. researchgate.net/project/The-Arab-Transformations-Project (accessed on 22 July 2021).

Acknowledgments: The authors would like to thank Timo Kivimaki and Rana Jawad, and three anonymous reviewers for helpful comments and suggestions.

Conflicts of Interest: The authors declare no conflict of interest.

\section{References}

Abbas, L. O. 2014. Islam and Modernity: The Case of Women Today. Journal of Cultural and Religious Studies 2: 297-305. [CrossRef] Abbott, Pamela, and Andrea Teti. 2015. The Arab Transformations Project. Available online: https://www.researchgate.net/project/ The-Arab-Transformations-Project (accessed on 18 May 2021).

Abdo Ahmad, Issam, and Ali Fakih. 2021. Does the legal form matter for firm performance in the MENA region? Annals of Public and Cooperative Economics. [CrossRef]

Abravanel, Martin D., and Ronald J. Busch. 1975. Political Competence, Political Trust, and the Action Orientations of University. The Journal of Politics 37: 57-82. [CrossRef]

Abu-Lughod, Lila. 2013. Do Muslim Women Need Saving? Cambridge: Harvard University Press.

Acemoglu, Daron, Simon Johnson, James A. Robinson, and Pierre Yared. 2005. From education to democracy? American Economic Review 95: 44-49. [CrossRef]

Aissa, El Hassane. 2012. The Arab Spring: Causes, Consequences, and Implications. Army War Coll Carlisle Barracks Pa. Available online: https:/ /apps.dtic.mil/sti/citations / ADA560779 (accessed on 15 July 2021).

Ali, Fatuma Ahmed, and Hannah Muthoni Macharia. 2013. Women, youth, and the Egyptian Arab spring. Peace Review 25: 359-66. [CrossRef]

Al-Kassimi, Khaled. 2021. A “New Middle East” Following 9/11 and the "Arab Spring” of 2011?-(Neo)-Orientalist Imaginaries Rejuvenate the (Temporal) Inclusive Exclusion Character of Jus Gentium. Laws 10: 29. [CrossRef]

Alqudsi-Ghabra, Taghreed. 2012. Creative use of Social Media in the Revolutions of Tunisia, Egypt \& Libya. International Journal of Interdisciplinary Social Sciences 2012: 6.

Al-Shammari, Nayef, and John Willoughby. 2019. Determinants of Political Instability across Arab Spring Countries. Mediterranean Politics 24: 196-217. [CrossRef]

Andersen, Ellen Ann, and M. Kent Jennings. 2010. Exploring Multi-Issue Activism. Political Science and Politics 43: 63-67. [CrossRef]

Anderson, Lisa. 2011. Demystifying the Arab Spring: Parsing the Differences between Tunisia, Egypt, and Libya. Foreign Aff. 90: 2.

Arampatzi, Efstratia, Martijn Burger, Elena Ianchovichina, Tina Röhricht, and Ruut Veenhoven. 2018. Unhappy development: Dissatisfaction with Life on the Eve of the Arab Spring. Review of Income and Wealth 64: S80-S113. [CrossRef]

Atkeson, Lonna Rae. 2003. Not All Cues Are Created Equal. The Conditional Impact of Female Candidates on Political Engagement. The Journal of Politics 65: 1040-61. [CrossRef]

BBC Trust. 2012. A BBC Trust Report on the Impartiality and Accuracy of the BBC's Coverage of the Events Known as the 'Arab Spring'. Available online: https://www.bbc.co.uk/bbctrust/our_work/editorial_standards/impartiality/arab_spring.html (accessed on 22 July 2021).

Bergh, Gina, and Franzisca Zanker. 2013. What Is the Evidence on the Impact of Employment Creation on Stability and Poverty Reduction in Fragile States. London: Overseas Development Institute.

Berman, Eli, Michael Callen, Joseph H. Felter, and Jacob N. Shapiro. 2011. Do Working Men Rebel? Insurgency and Unemployment in Afghanistan, Iraq, and The Philippines. Journal of Conflict Resolution 55: 496-528. [CrossRef]

Beissinger, Mark, Amaney Jamal, and K. Mazur. 2012. Who Participated in the Arab Spring? A Comparison of Egyptian and Tunisian Revolutions. Available online: http://www.princeton.edu/ \{\}mbeissin/beissinger.tunisiaegyptcoalitions.pdf (accessed on 22 July 2021).

Burris, Greg. 2011. “Lawrence of E-rabia: Facebook and the New Arab Revolt”, Jaddaliya. Available online: http:/ / www.jadaliyya. com/pages/index/2884/lawrence-of-e-rabia_facebook-and-the-new-arab-revo (accessed on 15 July 2021).

Byun, Chonghyun Christie, and Ethan J. Hollander. 2015. Explaining the intensity of the Arab Spring. Digest of Middle East Studies 24: 26-46. [CrossRef] 
Campante, Filipe R., and Davin Chor. 2012. Why Was the Arab World Poised for Revolution? Schooling, Economic Opportunities, and the Arab Spring. Journal of Economic Perspectives 26: 167-88. [CrossRef]

Campante, Filipe R., and Davin Chor. 2014. The People Want the Fall of the Regime: Schooling, Political Protest, and the Economy. Journal of Comparative Economics 42: 495-517. [CrossRef]

Cattle, Amy E. 2015. Digital Tahrir Square: An analysis of human rights and the Internet examined through the lens of the Egyptian Arab Spring. Duke Journal Computer E International 26: 417.

Cederman, Lars-Erik, Nils B. Weidmann, and Kristian Skrede Gleditsch. 2011. Horizontal Inequalities and Ethnonationalist Civil War: A Global Comparison. American Political Science Review 105: 478-95. [CrossRef]

Chokoshvili, Davit. 2011. The Role of the Internet in Democratic Transition: Case Study of the Arab Spring. Public Policy. Masters of Arts in Public Policy 51. Budapest: Central European University.

Citrin, Jack. 1977. Political Alienation as a Social Indicator: Attitudes and Action. Social Indicators Research 4: 381-419. [CrossRef]

Coleman, James S. 1963. Comment on the Concept of Influence. Public Opinion Quarterly 1963: 63-82. [CrossRef]

Coleman, James S. 1970. Political Money. The American Political Science Review 64: 1074-87. [CrossRef]

Collier, Paul, and Anke Hoeffler. 2004. Greed and Grievance in Civil War. Oxford Economic Papers 56: 565-95. [CrossRef]

Comunello, Francesca, and Giuseppe Anzera. 2012. Will the revolution be tweeted? A conceptual framework for understanding the social media and the Arab Spring. Islam and Christian-Muslim Relations 23: 453-70. [CrossRef]

Dewey, Taylor, Juliane Kaden, Miriam Marks, Shun Matsushima, and Beijing Zhu. 2012. The Impact of Social Media on Social Unrest in the Arab Spring. International Policy Program 5.

Diani, Mario. 2000. Social movement networks virtual and real. Information, Communication E Society 3: $386-401$.

Doherty, David, and Peter J. Schraeder. 2015. Patterns of Participation in a Revolution and Its Aftermath. In North Carolina State University Conference Paper. Raleigh: North Carolina State University.

Fakih, Ali, Nathir Haimoun, and Mohamad Kassem. 2020. Youth unemployment, gender and institutions during transition: Evidence from the arab spring. Social Indicators Research 150: 311-36. [CrossRef]

Fakih, Ali, and Pascal Ghazalian. 2019. Analyzing the Perceptions of Egyptian Youth about the Arab Spring. IZA Working Paper No. 12618. Available online: https://papers.ssrn.com/sol3/papers.cfm?abstract_id=3457662 (accessed on 15 July 2021).

Fisher, Ronald J. 1990. Needs Theory, Social Identity and an Eclectic Model of Conflict. In Conflict: Human Needs Theory. Edited by Burton John. London: Palgrave Macmillan UK, pp. 89-112.

Gire, Sabiha. 2017. The Role of Social Media in the Arab Spring. Pangaea Journal 1-10.

Glaeser, Edward L., Giacomo A. M. Ponzetto, and Andrei Shleifer. 2007. Why Does Democracy Need Education. Journal of Economic Growth 12: 77-99. [CrossRef]

Gurr, Ted R. 1970. Why Men Rebel. Princeton: Princeton University Press.

Henderson, John, and Sara Chatfield. 2011. Who matches? Propensity scores and bias in the causal effects of education on participation. The Journal of Politics 73: 646-58. [CrossRef]

Hoadley, J. Stephen. 1981. The Rise and Fall of the Basic Needs Approach. Cooperation and Conflict 16: 149-64. [CrossRef]

Huber, Daniela, and Lorenzo Kamel. 2015. Arab Spring: The role of the peripheries. Mediterranean Politics 20: 127-41. [CrossRef]

Hussain, Muzammil. M., and Philip N. Howard. 2012. Democracy's Fourth Wave? Information Technologies and the Fuzzy Causes of the Arab Spring. Available online: https:/ / papers.ssrn.com/sol3/papers.cfm?abstract_id=2029711 (accessed on 15 July 2021). [CrossRef]

Inglehart, Ronald, Pippa Norris, and Inglehart Ronald. 2003. Rising Tide: Gender Equality and Cultural Change around the World. Cambridge: Cambridge University Press.

Jackson, John S. 1973. Alienation and Black Political Participation. The Journal of Politics 35: 849-85. [CrossRef]

Juris, Jeffrey S. 2012. Reflections on\# Occupy Everywhere: Social media, public space, and emerging logics of aggregation. American Ethnologist 39: 259-79.

Kerson, Ben. 2011. A Social Media Revolution? Tunisia's Weight In. Six Estate David Reich. Available online: http:/ / sixestate.com/asocial-mediarevolution-tunisians-weigh-in/ (accessed on 15 July 2021).

Kettl, Donalad F. 2017. Can Governments Earn our Trust? New York: Polity Press. [CrossRef]

Khalid, Maryam. 2015. The peripheries of gender and sexuality in the "Arab spring". Mediterranean Politics 20. [CrossRef]

Kim, Susanna. 2011. Egypt's Mubarak Likely to Retain Vast Wealth. ABC News, February 2. Available online: https://abcnews.go. com/Business / egypt-mubarak-family-accumulated-wealth-days-military/story?id=12821073 (accessed on 15 July 2021).

Kivimäki, Timo. 2021. The Fragility-Grievances-Conflict Triangle in the Middle East and North Africa (MENA). An Exploration of the Correlative Associations. Social Sciences 10: 120. [CrossRef]

Klandermans, P. G. 2011. Mobilizing the unemployed: The social psychology of movement participation. In Unemployment and Protest: New Perspectives on Two Centuries of Contention. Oxford: Oxford University Press, pp. 39-58.

Klandermans, Pieter Gijsbertus. 1997. The Social Psychology of Protest. Oxford: Blackwell.

Lim, Merlyna. 2012. Clicks, cabs, and coffee houses: Social media and oppositional movements in Egypt, 2004-11. Journal of Communication 62: 231-48. [CrossRef]

Lotan, Gilad, Erhardt Graeff, Mike Ananny, Devin Gaffney, and Ian Pearce. 2011. The Arab Spring the revolutions were tweeted: Information flows during the 2011 Tunisian and Egyptian revolutions. International Journal of Communication 5: 31.

Lynch, Marc. 2011. After Egypt: The limits and promise of online challenges to the authoritarian Arab state. Perspectives on Politics 9: 301-10. [CrossRef] 
Lynch, Marc. 2013a. The Arab Uprising: The Unfinished Revolutions of the New Middle East. Paris: Hachette UK.

Lynch, Marc. 2013b. Twitter Devolutions. Foreign Policy 7. Available online: https://foreignpolicy.com/2013/02/07/twitterdevolutions / (accessed on 15 July 2021).

Mahmood, Saba. 2006. Feminist Theory, Agency, and the Liberatory Subject: Some Reflections on the Islamic Revival in Egypt. Temenos-Nordic Journal of Comparative Religion 42: 31-71. [CrossRef]

McCarthy, John D., and Mayer N. Zald. 1977. Resource Mobilization and Social Movement. A Partial Theory. American Journal of Sociology 82: 1212-41. [CrossRef]

McKay, Alistair. 2011. The Arab Spring of Discontent. E-International Relations. pp. 4-51. Available online: http:/ /www.e-ir.info/wpcontent/uploads / arab-spring-collection-e-IR.pdf (accessed on 15 July 2021).

Mello, Patrick A. 2010. Review article: In Search of New Wars: The Debate about a Transformation of War. European Journal of International Relations 16: 297-309. [CrossRef]

Morgan, Amanda. 1998. Corruption: Causes, Consequences, and Policy Implications. San Francisco: The Asia Foundation.

Muller, Edward N., and Thomas O. Jukam. 1977. On the meaning of political support. The American Political Science Review 1561-95. [CrossRef]

Muller, Edward N., Thomas O. Jukam, and Mitchell A. Seligson. 1982. Diffuse Political Support and Antisystem Political Behavior: A Comparative Analysis. American Journal of Political Science 1982: 240-64. [CrossRef]

Müller, Marion G., and Celina Hübner. 2014. How Facebook Facilitated the Jasmine Revolution. Conceptualizing the Functions of Online Social Network Communication. Journal of Social Media Studies 1: 17-33. [CrossRef]

Noland, Marcus, and Howard Pack. 2007. The Arab Economies in a Changing World. Washington, DC: Peterson Institute.

Ogbonnaya, Ufiem Maurice. 2013. Arab Spring in Tunisia, Egypt and Libya: A Comparative Analysis of Causes And Determinants. Alternatives: Turkish Journal of International Relations 12: 4-16.

Ottaway, Marina, and Amr Hamzawy. 2011. Protest Movements and Political Change in the Arab World. Washington, DC: Carnegie Endowment for International Peace, vol. 28.

Paasonen, Kari. 2020. Are the unhappy unemployed to blame for unrest? Scrutinising participation in the Arab Spring uprisings. Peace Economics, Peace Science and Public Policy 26. [CrossRef]

Parent, Olivier, and Abdallah Zouache. 2017. Role of Peer Effects in Social Protest. Bahrain: Arab Spring.

Parsons, Talcott. 1963. On the concept of influence. Public Opinion Quarterly 27: 37-62. [CrossRef]

Pérez, Xosé Soengas. 2013. The role of the Internet and social networks in the Arab Uprisings An alternative to official press censorship. Comunicar. Media Education Research Journal 2013: 21.

Pierce, Roy, and Philip E. Converse. 1989. Attitudinal Roots of Popular Protest: The French Upheaval of May 1968. International Journal of Public Opinion Research 1: 221-41. [CrossRef]

Porta, Donatella Della. 2008. Eventful Protest, Global Conflicts. Distinktion: Scandinavian Journal of Social Theory 9: 27-56. [CrossRef]

Radsch, Courtney C., and Sahar Khamis. 2013. In their own voice: Technologically mediated empowerment and transformation among young Arab women. Feminist Media Studies 13: 881-90. [CrossRef]

Sadiki, Larbi. 2000. Popular uprisings and Arab democratization. International Journal of Middle East Studies 32: 71-95. [CrossRef]

Saidin, Mohd Irwan Syazli. 2018. Rethinking the 'Arab Spring': The Root Causes of the Tunisian Jasmine Revolution and Egyptian January 25 Revolution. International Journal of Islamic Thought 13: 69-79. [CrossRef]

Salamey, Imad. 2015. Post-Arab Spring: Changes and challenges. Third World Quarterly 36: 111-29. [CrossRef]

Samin, Nadav. 2012. Saudi Arabia, Egypt, and the Social Media Moment. Arab Media E Society 15: 146-65.

Sears, David O., and John B. McConahay. 1973. The Politics of Violence: The New Urban Blacks and the Watts Riot. Boston: Houghton Mifflin.

Shah, Anwar, ed. 2007. Participatory Budgeting. Washington, DC: The World Bank. [CrossRef]

Solis, Alex. 2013. Does Higher Education Cause Political Participation? Evidence from a Regression Discontinuity Design. No. 2013: 13. Working Paper. Available online: https:/ / www.econstor.eu/handle/10419/82572 (accessed on 15 July 2021).

Tatarchevskiy, Tatiana. 2011. The 'popular 'culture of internet activism. New Media \& Society 13: 297-313.

Terrill, W. Andrew. 2011. The Conflicts in Yemen and US National Security. Carlisle Barracks: US Army War College Press. Available online: https:/ / press.armywarcollege.edu/monographs/588 (accessed on 22 July 2021).

Theiss, Maria, and Anna Kurowska. 2019. Being denied and granted social welfare and the propensity to protest. Acta Politica 54: 458-78. [CrossRef]

Tilly, Charles. 1978. From Mobilization to Revolution. Reading: Addison Wesley Publishing Company.

Tufekci, Zeynep, and Christopher Wilson. 2012. Social media and the decision to participate in political protest: Observations from Tahrir Square. Journal of Communication 62: 363-79. [CrossRef]

Ventura, Lorella. 2016. The "Arab Spring" and orientalist stereotypes: The role of orientalism in the narration of the revolts in the Arab world. Interventions 19: 282-97. [CrossRef] 